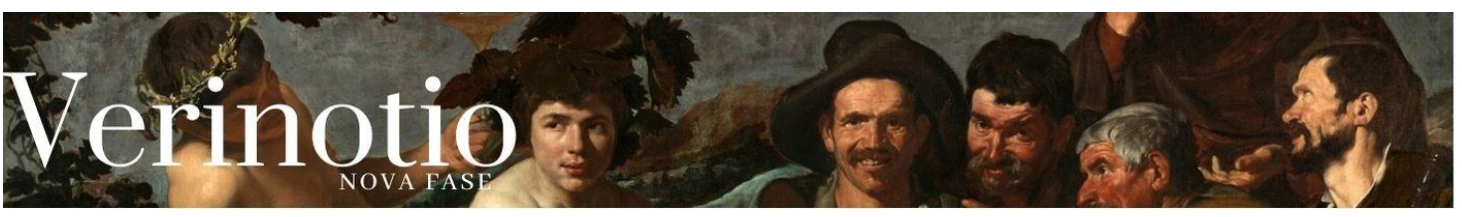

\title{
O que é possível dizer sobre as relações entre filosofia e sociedade em pleno século XXI?
}

\section{Ester Vaisman*}

Resumo: O objetivo principal do presente artigo é discutir as relações entre filosofia e sociedade nos escritos de Marx e Lukács. Para tanto, foram selecionados e analisados momentos específicos da obra dos dois autores, com especial atenção aos escritos do filósofo húngaro. A ideia é demonstrar o modo como ambos os autores articulam tais relações, por meio da noção de determinação social do pensamento, sem cair em postulações mecânicas, como é comumente entendida a relação filosofia e sociedade por marxistas e não marxistas.

Palavras-chave: Marx e Lukács; determinação social do pensamento; filosofia e sociedade.

\begin{abstract}
The main objective of this paper is to discuss the relationship between philosophy and society in the writings of Marx and Lukács. Therefore, specific moments in the work of the two authors were selected and analyzed, with special attention to the writings of the Hungarian philosopher. The idea is to demonstrate how both authors articulate such relationships, through the notion of social determination of thought, without falling into mechanical postulations, as the relationship between philosophy and society is commonly understood by Marxists and non-Marxists.
\end{abstract}

Keywords: Marx and Lukács; social determination of thought; philosophy and Society.

Para Mario Duayer (in memoriam)

\section{Introdução}

Como parte das homenagens a György Lukács, por ocasião do cinquentenário de sua morte e, também, em comemoração aos 25 anos da criação do grupo de pesquisa Marxologia - Filosofia e estudos confluentes, fundado por J. Chasin, pretendo retomar alguns aspectos da pesquisa que tenho desenvolvido ao logo dos últimos anos, sobretudo aquelas relativas ao legado do filósofo húngaro. O empenho aqui é o de resgatar do mesmo modo algumas das mais valiosas contribuições de Chasin para a devida recepção das obras de Marx e Lukács. Sem elas, teria sido impossível para mim e para diversas gerações de estudiosos adentrar com o devido cuidado na seara conturbada das interpretações a respeito. É claro que em se tratando de um artigo, não será possível aprofundar o teor das análises, ficando para outro momento e lugar

\footnotetext{
* Professora titular aposentada do Departamento de Filosofia da UFMG. Editora-chefe adjunta da Verinotio. E-mail. evaisman@fafich.ufmg.br
} 
a feitura de um balanço meticuloso dos principais aspectos da obra chasiniana, que, infelizmente, tem sofrido um persistente processo de apagamento, que não por acaso, vem ocorrendo não apenas nas instituições onde lecionou, mas perpetrado sobretudo por aqueles que, em momentos distintos, usufruíram de seus ensinamentos, participaram de pesquisas por ele orientadas, e também de algumas de suas iniciativas, principalmente no campo editorial.

O presente artigo foi elaborado de modo a contemplar autores e temas sobretudo Marx e Lukács - sobre os quais tive oportunidade de trabalhar com vistas à apresentação de trabalhos em congressos e seminários, à preparação de cursos em nível de graduação e pós-graduação e, também, evidentemente à elaboração de artigos publicados e não publicados.

Tendo em vista o caráter que resolvi imprimir ao texto, não foram mencionados e nem referenciados autores com quem estabeleci valiosa interlocução, vários deles ex-alunos, empenhados também na pesquisa e divulgação das linhas de investigação inauguradas por Chasin. Deles espero a devida compreensão.

\section{As conturbadas relações entre filosofia e sociedade}

De longa data, e com certeza de forma acentuada ou dominante em nossos tempos, por conta do predomínio de certas correntes filosóficas, à primeira vista, filosofia e sociedade não aparecem essencialmente vinculadas. Não me refiro apenas ao fato de que poucos admitem a complexa problemática da determinação social do pensamento, mas também a modos de concepção que não entendem como irrelevante o solo social da prática filosófica, nos quais, todavia, o nível resolutivo dos filosofemas transcorre num patamar extra-histórico ou extra-social, que se empenha por ser conotado como integralmente asséptico. Em outras palavras, mesmo aqueles que reconhecem a importância do assim chamado "contexto social" (pelo menos aparentemente), ao fim e ao cabo, consideram que os resultados obtidos pela reflexão filosófica são indiferentes ou se desocupam de qualquer finalidade que não seja aquela pensada como intrínseca ao próprio decurso da filosofia. Isto é, não reconhecem ou não admitem a destinação social do produto filosófico.

Para essa perspectiva e outras do mesmo naipe, tanto melhor será a filosofia quanto mais distante da sociedade ela se fizer. E se a isto for somada a negação também de sua gênese social, estaremos no quadro perfeito da filosofia divorciada das formas de sociabilidade. Num universo dessa ordem, qualquer conexão entre 
filosofia e sociedade é uma contingência subalterna ou falso problema.

Contudo, uma posição desse gênero não significa, automaticamente, a eliminação do homem como objeto da reflexão. A ética e a antropologia, por exemplo, em tematizações extrínsecas às formas de sociabilidade, são evidências de que a ruptura concepcional entre filosofia e sociedade não é necessariamente também fratura entre homem e filosofia. Mas, esta permanência de vínculo, nas condições dadas, ou seja, no interior de uma abordagem que concebe o homem como despojado de sua sociabilidade, não assegura que as condições de possibilidade da reflexão estejam postas, nem que seus processos e resultantes estejam protegidos de unilateralizações que mutilem ou mistifiquem, nem ainda que suas conclusões, contra todas as intenções e aparências, se ponham contra o homem e sua humanidade, precisamente porque é uma reflexão feita de costas para a sociabilidade.

Sugiro, com isso, que a fratura entre filosofia e sociedade paga um grande ônus, tanto em moeda filosófica quanto em saques concretos contra a individualidade e a universalidade do humano. Apenas a título de exemplificação, indico dois casos paradigmáticos, pois seria impossível aqui contemplar as diversas tendências e seus respectivos autores, que de um modo ou de outro, compartilham da posição acima denunciada. São dois expoentes de abordagens contrapostas que, contudo, denotam certos aspectos em comum a respeito do tema. E não por acaso.

Sabem todos, por exemplo, que o Wittgenstein, no Tractatus, trabalhou num ambiente de euforia que se seguiu à publicação dos Principia de Russell e Whitehead, tendo erigido o cálculo proposicional como padrão de inteligibilidade de todos os sistemas formais, postulando, em consequência, sua unidade, o que the permitiu conceber a lógica como um sistema total. Por sobre esta base, as questões semânticas, os problemas que dizem respeito às relações do sistema do mundo foram propostos de forma bastante ambiciosa.

Ora, como termina o Tractatus? Qual o seu último aforisma? Todos estão lembrados que o celebérrimo aforisma 7 afirma que: "O que não se pode falar, deve se calar". A respeito do que Wittgenstein está refletindo e, para o qual oferece uma resposta tão categoricamente impotente, como os aforismas antes do preceito do silêncio, está configurada a questão. Eu encadeio, para traduzi-la, os aforismas 6.44, a última sentença do aforisma 6.5, o aforisma 6.52. "O que é místico não é como o mundo é, mas que ele seja" (6.44); "Se uma questão pode ser colocada, poderá 
também ser respondida" (6.5); "Sentimos que, mesmo que todas as possíveis questões científicas fossem respondidas, nossos problemas vitais não teriam sido tocados. Sem dúvida, não cabe mais pergunta alguma, e esta e precisamente a resposta" (6.52) (WITTGENSTEIN, 1963, p. 128). No entanto, quando a resposta de uma filosofia à indagação sobre a natureza dos problemas vitais oferece somente o preceito de calar, que mais significa isso se não a confissão da falência dessa filosofia? Mas essa falência do silêncio, na boca íntegra e lúcida de Wittgenstein, diante do beco sem saída do seu próprio pensamento, estanca diante do abismo e seu silêncio é ruidoso, profundamente não conformista, uma denúncia da manipulação universal da vida no âmbito da sociedade contemporânea, ainda que seja feita na forma de protesto, a priori, impotente. Que isto seja contraditório no interior do próprio pensamento de Wittgenstein, só reforça o argumento de protesto, até porque, no aforisma 309 das Investigações Filosóficas, e não importa aqui se esta obra conflui ou rejeita a primeira de um quarto de século antes, lê-se o seguinte: "Qual o seu objetivo em filosofia?" e a resposta do próprio aforisma: "Mostrar à mosca a saída do mosquiteiro" (WITTGENSTEIN, 1975, p. 112).

Há traduções e interpretações que falam em vidro ao invés de mosquiteiro; ora, tanto faz mosquiteiro ou vidro, campânula que detém a mosca. Como as únicas moscas que fazem filosofia são os homens, e este aforisma é teleológico ético-prático, não há como negar que nele se manifesta o preceito de uma filosofia resolutiva. Portanto, de uma leitura não preconceituosa de Wittgenstein poderá decorrer, especialmente de seus lapsos e contradições, não apenas o ceticismo que dele é dominantemente extraído, mas de seus limites, de sua completa impotência, a priori, seu protesto silencioso pode ser retido, com ele ou contra ele, este silêncio que aspira por uma filosofia de bom caráter, por uma filosofia que em seu plano próprio seja resolutiva. Que não renuncie aos problemas vitais da vida, nem renuncie sobre eles deitar a luz indicativa dos pontos de saída; que ensine a romper os mosquiteiros ou vidros da manipulação e prefigure a transformação das moscas. Na boa e antiga tradição de filosofia em se ocupar do de onde e o para onde do homem no mundo.

À declaração de impotência de Wittgenstein, em face da manipulação contemporânea, junto agora a impotência política de Adorno. Tudo à guisa de ilustrar modos da prática filosófica em que a relação entre filosofia e sociedade não encontra sua essencial vinculação. A propositura da dialética negativa de Adorno é liberar a 
dialética da natureza afirmativa ${ }^{1}$ que possui de Platão a Marx, ou seja, desvincular a dialética de qualquer resultado positivo, torná-la independente de qualquer positividade. Desse modo, o perfil que almeja é alguma coisa próxima a um antissistema. Tendo como fundamento o princípio da não identidade e enfatizando o conceito de particular concreto, cuja significação reside mais na sua contingência do que na sua universalidade, mas, de qualquer modo sendo o lócus da determinação geral, ou seja, da estrutura social burguesa, a crítica de Adorno tem por objetivo a verdade não intencional, ou seja, a verdade reside no objeto, inclusive na matéria espiritual, isto é, no material das ideias, teorias, conceitos, romances, composições musicais. Mas, se a verdade está no sujeito, não está simplesmente à mão, é necessário o sujeito racional para que sua verdade seja liberada, de modo que o dado do objeto, na sua imediaticidade, o sujeito racional escapa sua ideia ou essência que é o seu conjunto social historicamente específico. Nesta prévia e rústica aproximação às concepções do antissistema de Adorno, tudo ou quase tudo parece indicar que filosofia e sociedade se encontram em conexão visceral. E que vale a pena favorecer ainda mais esta impressão, lembrando que desempenhou um papel importante nas anti-teorias de Adorno uma formulação lukácsiana em História e Consciência de Classe, qual seja: de que o problema da fetichização da mercadoria era o protótipo de todas as formas de objetividade e de todas as correspondentes formas de subjetividade na sociedade capitalista, incluindo os próprios esquemas do pensamento burguês. Mas, depois da Segunda Guerra, a fetichização e a reificação cedem lugar à possibilidade de uma catástrofe total - isto no pensamento de Adorno.

Para Adorno, o mal fundamental passa a ser a estrutura de dominação. Além disso, é preciso enfatizar que: ao lado do aspecto negativo da filosoficamente sofisticada crítica da ideologia de Lukács, um nível positivo que avançava da crítica social da consciência burguesa para uma ação da consciência revolucionária da categoria social do trabalho. Não importa aqui a maneira equivocada, hiper-hegeliana, com que Lukács na época formulou a tese, interessa sim salientar que, de todo modo, - marxismo aparecia então como um método cognoscitivo que conduzia a um programa de ação. Este segundo passo, portanto, jamais foi dado por Adorno, cuja rejeição à categoria social da atividade sensível ou do trabalho vai além da simples recusa à tese hiper-hegeliana do proletariado como sujeito-objeto idêntico da história.

\footnotetext{
${ }^{1}$ Cf. Adorno (2009).
} 
$\mathrm{Na}$ verdade, Adorno concebia a atividade do intelectual, sem qualquer relação de responsabilidade direta pelos seus efeitos junto ao público, sustentando que a atividade intelectual válida era revolucionária por si mesma. No envolver de suas formulações, Adorno chamará sua posição de Nichtteilnahme, isto é, a nãoparticipação. Segundo Adorno, a não-participação (Nichtteilnahme) era absolutamente necessária para manter viva a capacidade de experimentar o não idêntico, pois a participação é ser consumido, tragado, pois ela é característica do novo tipo antropológico que se identifica pela falta de curiosidade, pela falta de vontade da experimentação do não idêntico. Participar é, neste contexto, não querer conhecer nada de novo, nada que seja aberto e desprotegido. A isto é preciso agregar que toda insistência da negatividade em Adorno consistia na resistência em reproduzir no pensamento as estruturas de dominação e reificação manifestos na sociedade. E tem por consequência que, em lugar de reproduzir teoricamente a realidade, a razão deve se deter no plano crítico. Em suma, Adorno, procurando se assegurar de que a razão não se transformasse em participação deglutinadora, faz com que a dialética negativa anule a utilidade política e se transforme num fim em si mesma. A filosofia retorna simplesmente à filosofia. O nexo entre a filosofia e a sociedade é, mais uma vez, rompido. Mas quando o método da dialética negativa se perpassa como monopolização total, a própria filosofia está ameaçada. A nova esquerda, na década de 1960, censurava Adorno por ter conduzido a teoria crítica a um ponto morto; tornara-se algo estático, meramente contemplativo. Esta paralisia de Adorno, pergunto: não é, por caminhos totalmente diversos, o equivalente ao silêncio de Wittgenstein?

\section{Marx e o problema da sociabilidade}

No interior de abordagens similares àquelas referidas no item anterior, é comum surgirem críticas desairosas ao que supostamente Marx teria escrito a respeito do vínculo entre a esfera da sociabilidade e as formas genericamente denominadas de ideológicas, incluída aí, evidentemente, a filosofia, acusando-o, entre outros impropérios, de ter se deixado levar por "sociologismos". 2 Não obstante a impropriedade de tais imputações, não é o caso de se debruçar sobre elas: são

\footnotetext{
${ }^{2}$ Exemplo disso é o ensaio de autoria de Claude Lefort intitulado "Esboço de uma gênese da ideologia nas sociedades modernas", publicado na coletânea As formas da História, São Paulo, Editora Brasiliense, 1979. (Tradução Luiz Roberto Salinas Fortes e Marilena Chauí).
} 
inúmeras e provêm de variadas tendências e, ademais, o espaço que dispomos seria insuficiente para contemplá-las criticamente como merecem.

Ao compulsar as muitas páginas escritas por Marx ao longo de seu itinerário, tanto o formativo quanto o da maturidade, não há elementos textuais que comprovem a tese de um alegado "sociologismo" em seu pensamento. A não ser que levemos a sério as postulações derivadas da divisão de trabalho acadêmico em áreas estanques em que, de maneira geral, Marx é considerado "um dos clássicos da sociologia" ao lado de Durkheim e Weber, é evidente que sua posição não se confunde, em momento algum de suas análises, com algum tipo de autonomização ou desassociação da "sociedade" em sua pretensa nitidez e oclusão substancial. Dito em outros termos, a tese amplamente disseminada que postula a presença de um sociologismo na obra de Marx é a evidência cabal de que:

O complexo da determinação ontoprática e societária do pensamento não recebeu e nem tem recebido o devido tratamento por parte de grande número de intérpretes, a ponto de ser tomado, em grande número dos casos, em sentido predominantemente negativo, à la Durkheim (VAISMAN, 2006, p. 1).

Como consequência direta de afirmações dessa natureza, ou seja, o social concebido enquanto exterioridade em relação ao indivíduo, é fácil perceber as razões que levam à conclusão que ele não apenas constrange, freia, comprime e limita a vida individual, mas, sobretudo, as próprias operações do pensamento. "Sendo assim, esse efeito externo teria o poder de deformar, obstaculizar, ou mesmo impedir a produção do conhecimento" (VAISMAN, 2006, p. 1), gerando-se, desse modo, toda uma linha de interpretação, por exemplo, acerca de uma suposta teoria das ideologias em Marx, cujo fenômeno passa a ser identificado com o "falso socialmente necessário" com uma longa tradição entre pensadores marxistas e não marxistas.

A partir de um diapasão dessa natureza, avolumou-se e generalizou-se a ideia de que a noção de determinação social do pensamento implicaria necessariamente um elemento de caráter negativo que viria assim a impedir ou limitar a capacidade cognitiva dos indivíduos, que, portanto, se "encontrariam posicionados sempre a partir de pontos de vista particulares, condicionados historicamente, e dessa forma impossibilitados ao exercício objetivo da produção do saber" (VAISMAN, 1996, p. 198), ou seja, inabilitados a alçar um "ponto zero", expressão correntemente utilizada na área da epistemologia das ciências humanas.

No entanto, a sociabilidade em Marx, ao contrário do que normalmente lhe é 
imputado, apresenta-se de um modo completamente distinto, pois:

Responde como fonte primária ou raiz polivalente pelas grandezas e falácias do pensamento. De suas formas emanam carências e constrangimentos que impulsionam ao esclarecimento, ou pelo contrário, conduzem ao obscurecimento da consciência, em todos os graus e mesclas possíveis. De suas formações, que demarcam épocas, tempos de luz e afirmação do homem, ou de sombra e negação do mesmo. Se impõem e realizam, abrangendo todo gênero em suas tendências peculiares e contraditórias (CHASIN, 2009, p. 108).

No que diz respeito à relação indivíduo/sociedade, complexo categorial específico, diretamente vinculado ao modo como Marx abordou e tematizou a sociabilidade, ele se converteu, do mesmo modo, em objeto de inúmeras polêmicas, por isso, é importante também, nesse momento da exposição, aduzir algumas considerações de cunho explicativo com vistas a um devido posicionamento diante do assunto.

Em outro lugar cheguei a afirmar que:

O desapreço por Marx, derivado do desconhecimento de sua obra e da catástrofe impudente do Leste Europeu, levou inclusive intérpretes bemintencionados a navegar e submergir em ideias no mínimo problemáticas, quando a grande tematização do homem está em Marx - os indivíduos sociais, a individuação, a formação social da individualidade. 0 reconhecimento do forte vínculo entre indivíduo e sociabilidade, quando bem fundamentado, amparado nas formulações do próprio autor ao longo de sua obra, permite-nos compreender que a categoria da individualidade em Marx não é nem pode ser compreendida de outro modo, a não ser recaindo em mitos e supostos naturalistas ou transcendentais (VAISMAN, 2009, p. 442).

Ainda nesse mesmo artigo, linhas à frente, acrescento o seguinte esclarecimento:

Por ora, importa lembrar que, já na VI Tese Ad Feuerbach, com objetivo de rejeitar o naturalismo presente em Feuerbach, Marx é enfático ao afirmar que "[...] a essência humana é o conjunto das relações sociais" (MARX; ENGELS, 2007, p. 534). O conteúdo desse conhecido, mas mal interpretado aforismo, indica uma noção substancialmente diferente das concepções naturalistas ou transcendentais, de longa tradição na história da Filosofia. Ademais, tal noção - vale a pena repetir - não deve ser tomada como um sociologismo à la Durkheim. Em verdade, postulações dessa natureza são estranhas ao pensamento de Marx, pois é no interior do complexo e contraditório campo da interatividade social, segundo ele, que a individualidade se forja, simultaneamente à produção do próprio mundo social, emergindo, dessa forma, não como dois polos excludentes, mas como âmbitos da existência humana que se determinam mutuamente (VAISMAN, 2009, p. 442).

De fato, à atribuição de um "sociologismo" em Marx foi associada à tese de que a individualidade nada mais seria do que um apêndice condicionado e conformado pelo "meio social", não possuindo assim identidade própria, autoentificada. Como tais postulações aparecem, de modo geral, correlacionadas, é mister tratá-las aqui do modo como convém a um escrito cujo objetivo final é discutir as relações entre filosofia 
e sociedade. Em um tal contexto, menções ao processo de individuação se tornam necessárias.

Em suma, parece que obviedades ainda precisam ser ditas e repetidas inúmeras vezes, numa espécie de espiral infernal em que se tenta convencer as pessoas que Marx "não falou isso nem disse aquilo". Como parece não existir alternativa, recordemos então algumas passagens de escritos fundamentais do autor em que é possível identificar as características mais gerais de sua real posição a respeito do tema em foco.

Já há algum tempo, venho insistindo, na trilha aberta por Chasin, ${ }^{3}$ na denúncia das interpretações grosseiras e reducionistas acerca do complexo da determinação social do pensamento. De fato, não se trata de uma questão fácil de ser devidamente esclarecida, mas é necessário convir que houve e ainda há uma certa má vontade em buscar a sua devida elucidação; muito mais fácil e cômodo, adequado ao tempo presente, é continuar insistindo na mesma tecla ao invés de realizar um confronto leal e honesto com os textos: procedimento que Chasin denominou de análise imanente. Seguindo à risca as várias pistas e indicações concretas nos seus escritos desde a década de 1970, constata-se que não se trata de algo parecido com a conhecida "análise estrutural", procedimento adotado pelos filósofos uspianos da velha geração, nem muito menos com alguma técnica específica da "análise de discurso", proposta mais recente e mais ao gosto do noviciado. Diferentemente das hermenêuticas em voga, sequazes que são de abordagens nascidas em meio à proliferação das correntes irracionalistas, a análise não se confunde com operações que imputam ao texto vivências de ordem subjetiva por parte do leitor. Ao contrário, não se trata de identificar, como contemporaneamente ocorre, leitura à:

\begin{abstract}
Interpretação, à atribuição de sentido ao texto ou documento pelo pesquisador/intérprete. $O$ que põe simultaneamente a equivalência absoluta das várias interpretações ou operações hermenêuticas, uma vez que a questão da verdade sobre o objeto em exame está totalmente afastada do âmbito da investigação, seja como questão sem solução, seja como um falso problema (VAISMAN, Alves, 2009, p. 8).
\end{abstract}

O próprio Chasin é enfático ao justificar a importância de uma tal propositura. Diz ele:

Numa época devastada pela equivalência de 'leituras', [é necessário] ressaltar uma questão fundamental: reproduzir pelo interior mesmo da reflexão

\footnotetext{
${ }^{3}$ Ver a respeito CHASIN, 2009.
} 
marxiana o trançado determinativo de seus escritos, ao modo como o próprio autor os concebeu e expressou. Procedimento, pois, que adquire articulação e identidade pela condução ininterrupta de uma analítica matrizada pelo respeito radical à estrutura e à lógica inerente ao texto examinado, ou seja, que tem por mérito a sustentação de que antes de interpretar ou criticar é incontornavelmente necessário compreender e fazer prova de haver compreendido (CHASIN, 2009, p. 25).

A respeito do devido entendimento do significado da análise imanente, Ronaldo Vielmi Fortes e eu tivemos oportunidade de ressaltar na apresentação à tradução brasileira de $A$ destruição da razão, de autoria de G. Lukács, que:

\begin{abstract}
Contrariamente ao que uma observação mais ligeira sobre a questão poderia denotar, não se trata de simples alinhavo de paráfrases ou de atulhamento do escrito com citações em grande quantidade, enumeradas acriteriosamente pelo intérprete de acordo com suas próprias crenças e convicções, mas procedimento investigativo de rigor que almeja identificar a estrutura categorial das obras, alvo da atenção do filósofo. Trata-se, enfim, de atitude de respeito ao texto, em que o intérprete se subordina ao sentido nele existente objetivamente. Que se trata de empreendimento de difícil execução, não resta a menor dúvida. Muito mais cômodo e fácil seria simplesmente atribuir ao material estudado o significado que subjetivamente o intérprete é capaz de formular, à revelia da própria tessitura significativa presente no escrito (VAISMAN; FORTES, 2020, pp. XI-XII).
\end{abstract}

Dito isso, é chegada a hora de trazer à tona alguns momentos da reflexão marxiana acerca da questão sobre a sociabilidade, suas relações com a individualidade e as maneiras de pensar. Evidentemente, não é o caso - como já mencionado acima de esgotar nesse momento todas as dimensões que tal tematização encerra. ${ }^{4} \mathrm{O}$ que se pretende aqui é algo mais modesto e, evidentemente, circunscrito pelo espaço disponível.

Com o fito de colocar, de início, a questão de maneira direta e sintética, para a seguir desdobrá-la da maneira mais conveniente possível, ouso afirmar que a grande descoberta filosófica de Marx foi a da sociabilidade como atividade sensível. No entanto, em virtude do cenário nada auspicioso, tanto no terreno acadêmico como fora dele, decorrente dos "mal-entendidos interpretativos", distorções e ainda simplificações vulgares, ${ }^{5}$ ao dar início a uma exposição sobre qualquer tema específico em Marx - sobretudo a questão da sociabilidade - impõe-se, antes de mais nada, tratar, mesmo que de modo sumário, dos lineamentos básicos do novo padrão de racionalidade instaurado no seu itinerário intelectual. Já em minha tese de doutorado, procurei demonstrar à exaustão que na fase formativa de seu pensamento próprio, é

\footnotetext{
${ }^{4}$ Em minha tese de doutorado intitulada A determinação marxiana da ideologia, defendida em 1996, pude me dedicar ao tema da determinação social do pensamento em Marx com mais vagar.

${ }^{5}$ Cf. Vaisman (2018).
} 
possível identificar, por exemplo, o reconhecimento de Marx acerca "da vinculação entre o momento real e o momento ideal, como fundada no interior da atividade prática enquanto tal" (VAISMAN, 1996, p. 131). Tal conclusão foi obtida a partir de um percurso investigativo que lidou com os escritos de Marx (e também Engels, como no caso das obras $A$ ideologia alemã e $A$ sagrada família) em que é afirmada uma das suas conquistas fundamentais na lida crítica com a filosofia especulativa: No centro do processo objetivo real, por conseguinte, emerge a atividade objetiva, a partir da qual os homens, modificando a natureza, produzem seus meios de vida e, por via de consequência, a si próprios. Mas a produção dos meios de vida, resultante da atividade de indivíduos humanos reais, ou seja, não abstraídos das suas condições efetivas de existência, não é considerada apenas do ponto de vista de sua "reprodução física [...]. Trata-se, muito mais, de uma determinada forma de atividade dos indivíduos, determinada forma de manifestar sua vida, determinado modo de vida deles" (MARX; ENGELS, 2007, p. 87).

Importante assinalar na passagem acima que os autores:

Não restringem ou reduzem a produção dos meios de vida àqueles diretamente necessários à reprodução física propriamente dita, mas entendem os indivíduos produzindo seu modo de vida, vale dizer, produzindo todas as dimensões da vida tomada em seu conjunto, em sentido amplo e não apenas aqueles aspectos voltados às suas necessidades de reprodução física ou biológica. Ao referir, consequentemente, que os indivíduos produzem seu modo de vida, é identificado o caráter efetivante da atividade humana, por meio da qual os homens produzem a si próprios no sentido abrangente do termo, ou seja, entificam o seu próprio modo de vida no contexto de dada materialidade específica, isto é, histórico-social, que possui caráter objetivo (VAISMAN, 1996, pp. 132-33).

Ora, independentemente do "espanto" eventual que tal afirmação possa gerar entre os possíveis leitores, a devida explicitação da rota intelectual de Marx, identificada e analisada de modo competente por Chasin, pode evidenciar como tal descoberta se verificou.

Contudo, não é possível, nesse espaço, identificar com detalhe o modo como Marx constituiu sua própria concepção da sociabilidade, mas é necessário, no entanto, apontar que tal concepção se constituiu em um contexto em que a sua lida crítica confrontou o idealismo de Hegel e dos neohegelianos, e que, dado o seu caráter ontocrítico, faceou a especulatividade da filosofia anterior, aí compreendida com destaque a ontonegatividade da política, o que o levou ao deciframento da "anatomia da sociedade civil" após, um longo e intenso percurso voltado aos estudos de economia política. Sendo assim, buscarei sintetizar alguns nódulos categoriais 
articulados indissoluvelmente com o problema em tela.

Resumidamente são eles:

A atividade sensível determina o homem enquanto individualidade ativa, socialmente efetivada, capacitado a construir seu próprio mundo; este, por isso mesmo, é atividade sensível enquanto universo posto pela ação humana. O homem, por sua vez, ao construir seu mundo constrói a si próprio, sendo igualmente, atividade sensível (VAISMAN, 1996, p. 186).

Em outras palavras, a autoentificação humana e de sua mundaneidade específica, por meio da atividade prática, objetiva e concreta enquanto tal é que torna possível compreender as razões que levam Marx a postular a sociabilidade enquanto condição de possibilidade do pensamento, qualquer que seja a figura específica com que se apresente: filosofia, arte, ciência, religião...

Inúmeras são as passagens dos escritos de Marx que comprovam essas assertivas. No momento, basta lembrar de uma em especial presente nos Manuscritos de Paris em que o autor sublinha, de um lado, a impossibilidade de "fixar a 'sociedade' como outra abstração frente ao indivíduo" e, de outro, o reconhecimento da:

Atividade do indivíduo, qualquer que seja, [...] implica a mediação da
sociabilidade. Vale dizer, nos termos dos Manuscritos econômico-filosóficos,
a exteriorização individual implica e confirma a sociabilidade [...] na medida
em que todo modo de efetivação individual - prático/teórico - se dá na trama
da interatividade humano-social. Enquanto tal, essa efetivação é apropriação
da vida humana (VAISMAN, 1996, p. 188).

Ademais, convém sublinhar mais uma vez o teor da conquista obtida por Marx em um momento particularmente crucial representado pelos manuscritos aqui referidos: a existência individual em si mesma é também atividade social e apropriação do mundo.

Portanto, o esforço de Marx, nesse momento de seu itinerário intelectual, frente à tradição de cunho idealista, assim como a crítica dessa mesma tradição realizada pelos neohegelianos, em particular por Feuerbach, é demonstrar, a partir de um processo árduo de autoesclarecimento, o papel da atividade sensível na constituição da mundaneidade humana e do próprio indivíduo e a interrelação insuprimível entre individualidade e sociabilidade, rejeitando assim toda a abordagem que afirma apenas a dimensão abstrata da atividade humana como inerentemente humana e o seu corolário: a realidade concreta enquanto mero submundo da existência. ${ }^{6}$

${ }^{6}$ Cf. Teses ad Feuerbach, em particular a primeira. 
O certo é que nos Manuscritos de Paris, nas obras imediatamente subsequentes e, do mesmo modo, em sua ampla maturidade, a reflexão de Marx tem na atividade prática concreta o seu eixo norteador. Evidências claras, nesse sentido, podem ser identificadas, como já salientamos, em seus escritos da década de 1840, assim como as suas repercussões no surgimento e configurações nas formas específicas com que o pensamento é exercitado. E é natural que essas evidências surjam no contexto da crítica à filosofia especulativa, como também tivemos a oportunidade de indicar. Resta agora referir um trecho de $A$ ldeologia alemã, sobejamente conhecido, para sublinhar o processo que Marx percorre para constituir de modo irretorquível os vínculos entre e o ser dos homens e seus atributos, no caso, o pensamento: "os homens são produtores de suas representações, de suas ideias, mas os homens reais e ativos" (MARX; ENGELS, 2007, p. 94), ou seja, as ideias, as representações estão diretamente entrelaçadas com a atividade que os indivíduos realizam e ao transformá-la "transformam também com esta sua realidade, seu pensar e os produtos de seu pensar, não é a consciência que determina a vida, mas a vida que determina a consciência" (MARX; ENGELS, 2007, p. 94). Desse modo, a devida compreensão do caráter social do pensar e dos seus produtos passa necessariamente pelo reconhecimento da impossibilidade de abstraí-lo, separá-lo ou isolá-lo de seus portadores reais, em sua atividade concreta, historicamente delimitada.

Colocando a questão nos seus devidos termos, é perfeitamente perceptível que Marx se encaminha na direção de afirmar a produção do pensar e de suas figuras específicas como momento da prática humana concreta, constituído no interior da própria sociabilidade, em nítido contraste com a posição filosófica de cunho idealista então predominante no ambiente intelectual alemão. Ademais, é imperioso dizer que não se trata de uma postulação de caráter economicista ou coisa que o valha. Tratase de acordo com as palavras de Chasin de:

Discernir condições, possibilidades ou impedimentos de atualização, é deslindar processos genéticos, o que só é possível de elisão em face do incondicionado, do absoluto, cuja figura, aliás, ao inverso de consagrar uma presença de validade infinita, remete ao vazio, pois basta desconhecer ou abstrair a origem e o desenvolvimento de algo, para que o mesmo assuma a máscara do eterno (CHASIN, 2009, p. 110).

E este decididamente não é o procedimento peculiar de Marx, muito ao contrário, ele reiteradamente denuncia, por exemplo, o "ponto de vista da economia política" cuja abordagem consagra a eternização das categorias específicas da produção capitalista, e as universaliza por meio de um processo dissolutor de sua gênese 
histórica específica, cancelando assim a transitoriedade de sua existência. Por via de consequência, o campo da efetiva interatividade social identificada por Marx na crítica ontológica ao idealismo e à própria política ganhou contornos efetivos quando o autor se volta de modo vigoroso à crítica da economia política já em plena maturidade. Impulsionado pelas conquistas teóricas resultantes do itinerário anterior, Marx pode conferir um tratamento crítico específico à relação entre os quadros da sociabilidade capitalista e os modos de configuração teórica que daí emergiram. Trata-se de momentos eloquentes em que a questão da determinação social do pensamento desponta na elucidação das teorias econômicas analisadas por ele.

Naturalmente, os textos mais adequados para identificar a posição de Marx nesse quesito se encontram nos manuscritos de As teorias da mais-valia, nos quais analisa criticamente as formações ideais da ciência econômica com o objetivo de avaliar os "seus diferentes graus de aproximação da realidade, nunca deixando de apontar os horizontes sociais dos quais essas promanam" (VAISMAN, 1996, p. 206).

Para os fins do presente artigo, inicialmente, iremos tecer algumas considerações sobre as análises voltadas a Adam Smith, em primeiro lugar, tendo em vista que com ele "a economia política atingira certa plenitude" (MARX, 1983, p. 597). Contudo, não obstante as suas conquistas teóricas:

\footnotetext{
Smith move-se com grande ingenuidade em contradição contínua. Ora investiga as conexões causais das categorias econômicas ou a estrutura oculta do sistema burguês. Ora junta a essa pesquisa as conexões tais como se exteriorizam na aparência dos fenômenos da concorrência (MARX, 1983, pp. 597-8).
}

Ademais, Marx constata a existência de "dois ângulos, um penetra no nexo causal, na fisiologia, por assim dizer, do sistema burguês; o outro apenas descreve, cataloga e relata, ajustando a definições esquematizantes, o que se revela exatamente no processo vital, tal como se mostra e aparece" (MARX, 1983, p. 598).

É importante ressaltar, no entanto, que embora Marx denuncie a existência desses dois ângulos, que se desenvolvem paralelamente na analítica smithiniana, redundando continuamente em contradições, ao mesmo tempo considera que isso se justificava, pois Smith "tinha pela frente uma tarefa dupla e difícil de ser levada a cabo, dado o estágio inicial da aproximação feita pelo economista junto à realidade capitalista da época" (VAISMAN, 1996, p. 219).

Com vistas a sumariar a avaliação marxiana da obra de Smith, pode-se dizer que 
a teorização econômica realizada por este último:

Representou, no plano das formações ideais, o ponto de vista burguês na sua fase ascensional. Nessa medida, em diversos momentos, essa teorização foi capaz de apreender vários aspectos fundamentais da constituição interna do sistema capitalista, mas, ao mesmo tempo, contraditoriamente, pela mesma razão, em outros momentos, se deteve apenas em seu nível superficial e aparente. Donde, as contradições detectadas por Marx não derivarem da falta de perspicácia teórica de Smith enquanto cientista, mas do próprio estágio de desenvolvimento do ponto de vista burguês que ele manifesta. Isso induz tanto seus acertos quanto seus erros (VAISMAN, 1996, p. 214).

O caso de David Ricardo é mais contundente, dados os avanços que sua doutrina econômica significou em comparação com seus antecessores, sobretudo Smith. Mas, do mesmo modo que esse último, o pensamento de Ricardo apresenta contradições insolúveis sobretudo no tocante ao modo como concebe o trabalho enquanto única fonte de valor de troca e fonte ativa do valor de uso, mas onde, simultaneamente, o capital é o regulador da produção e verdadeira fonte da riqueza. Em especial, a obra de Ricardo expressa:

Apenas a essência da produção capitalista ou, se se quer, do trabalho assalariado; do trabalho que se torna estranho a si mesmo e que a riqueza por ele criada é enfrentada como riqueza alheia, a sua própria força produtiva como força produtiva de seu produto, seu enriquecimento como empobrecimento de si mesmo, seu poder social como poder da sociedade sobre ele (MARX, 1985, p.1307).

Mas o que importa evidenciar nas análises de Marx acerca principalmente da contraditoriedade em que se movem os economistas, é que o desenvolvimento real da economia burguesa que proporciona essa expressão teórica ao mesmo tempo contraditória e brutal.

Ainda que o volumoso manuscrito intitulado Teorias da Mais-valia se constitua um manancial infindável de fontes para identificar o caráter da noção de determinação social do pensamento em Marx, não podemos, por razões já ventiladas acima, prosseguir no exame das várias páginas que compõe esse escrito. Mas ainda há espaço para alinhavar alguns comentários finais a respeito. Percebe-se, ao longo de suas análises, que, em várias ocasiões:

Marx explicita o lócus originário dos desdobramentos teóricos que
caracterizam o itinerário da ciência econômica, tanto na sua feição clássica
quanto na sua feição vulgar: a origem, desenvolvimento e a dissolução da
economia política clássica, bem como na emersão das formulações 'vulgares',
correspondem [por meio de inúmeras mediações] no plano teórico à
imanência das diferentes clivagens sociais no quadro de sua
contraditoriedade efetiva (VAISMAN, 1996, p. 229).

Em suma, a título de conclusão desta parte do texto dedicada a Marx, tem-se as 
condições para estabelecer as seguintes assertivas:

1) "a dimensão fundamental da noção de determinação social do pensamento, ao contrário do que é genericamente suposto, diz respeito à sociabilidade como condição de possibilidade do pensamento".

2) "não significa restrição ou canga oposta ao pensar. Do mesmo modo não significa condicionamento unilateral de verdade ou falsidade; é pois, ambivalente, se especificando de acordo com óticas e angulações sociais possíveis, dentro de limites históricos sempre mutáveis e de acordo com os graus de maturação das entificações" (VAISMAN, 1996, p. 244).

\section{A contribuição de Lukács}

Nos dias de hoje, devido a publicação de importantes obras de Lukács em português, é de se esperar que o público interessado já tenha conhecimento que o filósofo se dedicou, nos seus últimos anos de vida, a um projeto concebido como uma contribuição para a renovação do marxismo. Colocado em termos breves, o seu objetivo central era demonstrar que o pensamento de Marx foi se constituindo a partir do reconhecimento de uma determinada forma de ser - a social -, o que lhe permitia pensar em um projeto ambicioso de formulação de uma ontologia a partir dos escritos do filósofo alemão.

Quando tomei conhecimento desse projeto, ainda nos anos 1970, a reação imediata passou por um questionamento inevitável: por que Lukács insiste em tratar de um tema tão inusual em sua obra da maturidade, qual seja, a possível existência de uma ontologia em Marx (o que causou grande estranheza até em seus discípulos mais diletos), questão que tem suscitado recusa de quantos se dizem interessados por assuntos afins, que a entenderiam por inadmissível?

Segundo Lukács, esta recusa e este estranhamento se devem ao fato de o critério gnosiológico ter auferido predomínio no campo filosófico: a posição gnosiológica se refere ao saber e, como tal, emerge enquanto atributo do campo da subjetividade; a posição ontológica, pelo contrário, refere-se diretamente ao campo do ser e, portanto, à objetividade dela mesma. A posição ontológica distancia-se da unilateralidade que advém da postura gnosiológica, sempre especulativa em relação à organização e atividade da subjetividade e, quando seguida adequadamente, orienta a pensar as coisas rigorosamente a partir de seus próprios nexos, alcançando uma totalidade mais 
complexa.

A primeira vez que menções deste tipo apareceram em português foi em 1969, quando a Editora Paz e Terra publicou o livro Conversando com Lukács (cujo original veio a lume em 1967, portanto, no mesmo ano em que ele autoriza a republicação de História e consciência de classe com o "Prefácio" escrito para esclarecer seus novos posicionamentos), uma série de entrevistas feitas com o pensador húngaro por Leo Köfler, Wolfgang Abendroth e Hans Heinz Holz. Logo na primeira conversa, cujo título era "Ser e consciência", Holz indaga a Lukács quais eram os pressupostos ontológicos, que nem sempre eram tratados explicitamente, da sua Estética:

\begin{abstract}
"Até que ponto certas posições de sua Estética são definidas e condicionadas por pressupostos ontológicos? [...] Existe alguma coisa que se possa definir como uma ontologia marxista? Que sentido pode ter o termo 'ontologia' numa filosofia marxista?" Ao que Lukács responde: "Suponho que sempre é preciso começar - e isto vale para os cientistas tanto como para qualquer outra pessoa - por questões da vida cotidiana" (HOLZ; KOFLER; ABENDROTH, 1969, p. 11).
\end{abstract}

Ideia semelhante já fora anunciada na sua Estética (Sobre a peculiaridade do estético, de 1963) e era agora reafirmada nesta entrevista. É necessário partir da cotidianidade em todas as dimensões: seja na da vida das pessoas, seja no plano da ciência, da arte ou da filosofia. Isso porque:

$\mathrm{Na}$ vida cotidiana, os problemas ontológicos se colocam num sentido muito grosseiro. Darei um exemplo bastante simples: quando alguém caminha pela rua - mesmo que seja, no plano da teoria do conhecimento, um obstinado neopositivista, capaz de negar toda a realidade - ao chegar a um cruzamento, deverá por força convencer-se de que, se não parar, um automóvel real o atropelará, realmente; não lhe será possível pensar que uma fórmula matemática qualquer de sua existência estará subvertida pela função matemática do carro ou pela sua representação da representação do automóvel. Tomo deliberadamente um exemplo tão simples para mostrar como na nossa vida as diversas formas de ser estão sempre unidas entre elas e o inter-relacionamento constitui o dado primário (HOLZ; KOFLER; ABENDROTH, 1969, pp. 11-2).

Após este singelo e elucidativo exemplo, o pensador continua:

Ora, as atividades espirituais do homem não são, por assim dizer, entidades da alma, como imagina a filosofia acadêmica, porém formas diversas sobre a base das quais os homens organizam cada uma de suas ações e reações ao mundo externo. Os homens dependem sempre, de algum modo, destas formas, para a defesa e a construção de sua existência (HOLZ; KOFLER; ABENDROTH, 1969, p. 12).

Trata-se da ideia de que as atividades de ordem cultural, científica, filosófica e artística, em todos os níveis em que se manifestam, são sempre respostas a problemas postos na vida cotidiana. Aquelas se distanciam e se autonomizam, mas, contudo, invariavelmente a têm como seu ponto de partida e, também, de chegada, ainda que 
por meio de um conjunto complexo de mediações. No prefácio à Estética, Lukács recorre, nesse sentido, à figura da vida cotidiana como um "grande rio" de cujo leito se destacam as atividades espirituais superiores: os problemas sobre os quais estas atividades se debruçam são, de maneira direta ou indireta, colocados pela vida cotidiana e de alguma maneira as respostas formuladas retornam a ela, podendo, em certas ocasiões, contribuir decisivamente para mudança do rumo com que ela caminha.

Além de destacar a fundamental importância da vida cotidiana para a devida elucidação do sentido e significado das formações ideais, e, na:

\begin{abstract}
Contramão das tendências dominantes, mesmo no interior do marxismo, as linhas diretrizes da investigação de Lukács são devidas ao reconhecimento marxiano da objetividade como propriedade originária dos entes. Já na fase de preparação de sua Estética, Lukács procurou investigar a base ontológica tanto do pôr estético quanto da recepção da obra de arte (VAISMAN, 2009, p. 446).
\end{abstract}

Contudo, "ao assinalarmos acima a provável existência de um fio condutor, principalmente entre a Estética e a Ontologia, não resulta de imediato a conclusão de que Lukács tenha aderido, sem mais, à própria expressão, ainda que, como afirma Oldrini, "[...] mesmo lá onde a coisa, o nexo conceitual já exista em germe, falta a palavra para exprimi-lo" . Em verdade, Lukács nutria sérias desconfianças e suspeitas em relação à própria palavra, resistindo em utilizá-la; "[...] para ele, tomando a conotação que Ihe fora conferida por Heidegger, ela só tem um valor negativo" (OLDRINI, 2002, apud VAISMAN, 2009, p. 446).

No decorrer da entrevista concedida a Heinz, Holz e Abendroth, Lukács reconhece justamente o que Oldrini assinala na citação acima, ou seja, que, durante muito tempo, tinha restrições ao termo ontologia, e só veio a utilizá-lo tardiamente. Justifica tal decisão alegando que a palavra "ontologia" estava associada, na filosofia contemporânea, ao existencialismo de Sartre e a Heidegger. E nessa direção, no volume I da Ontologia, pode-se constatar a presença de críticas severas a Heidegger - muito embora o filósofo húngaro, morto em 1971, não tenha assistido ao pleno triunfo das concepções que consagram o homem derrelito, denominação que empregava ao se reportar a Heidegger -, como já havia feito a Sartre no livro Existencialismo ou marxismo. De fato, é bom deixar aqui assinalado que, em vários aspectos, os comentários críticos dirigidos a Heidegger em Para uma ontologia do ser social são mais contundentes e amplos do que aqueles formulados no livro $A$ destruição da razão, sobre o qual faremos algumas referências ainda no presente 
artigo.

De todo modo, a linguagem em tom coloquial utilizada por ocasião das "conversações" permite a Lukács se valer de certa ironia ao se referir ao termo:

\begin{abstract}
Usamos a bela palavra 'ontologia', à qual eu mesmo me estou habituando, mas dever-se-ia dizer: o enigma se desvenda no exato momento em que descobrimos a forma de ser que produz este novo movimento do complexo. $O$ fato de que novos fenômenos se deixem deduzir geneticamente sobre $o$ fundamento de sua existência cotidiana é apenas um momento de uma conexão geral, isto é, significa que o ser é um processo de tipo histórico (HOLZ; KOFLER; ABENDROTH, 1969, p. 19).
\end{abstract}

A bem da verdade, a propósito do termo "ontologia", é forçoso reconhecer que é algo muito diverso discutir a questão ontológica nos dias de hoje do que há três séculos, para dizer o mínimo. Ora, o clima teórico que envolvia a questão até o século $\mathrm{XVIII} \mathrm{era} \mathrm{completamente} \mathrm{distinto} \mathrm{daquele} \mathrm{que} \mathrm{vivemos} \mathrm{hoje} \mathrm{e} \mathrm{ao} \mathrm{qual} \mathrm{estamos} \mathrm{direta}$ ou indiretamente condicionados. Tal indicação não é um dado óbvio, mas visa a problematizar uma grave clivagem, que Lukács não desconhecia. As dificuldades para o devido enfrentamento da questão ontológica hoje são enormes e já eram conhecidas por Lukács. "Tais dificuldades, grosso modo, poderiam ser atribuídas inicialmente às tendências que têm como ponto de partida o criticismo kantiano, que se impuseram na viragem do século XIX para o $\mathrm{XX}$, com a redução da filosofia ao circuito da problemática do conhecimento" (VAISMAN, 2006, p. 6).

De fato, os interessados pela obra tardia de Lukács, sobretudo Para uma Ontologia do Ser Social, sabem que se trata de esforço de ampla envergadura e cuja devida compreensão e interpretação é um projeto ainda inacabado, a despeito de esforços de vários de seus intérpretes. A complexidade do tema em si já se apresenta como um desafio, muitas vezes de aparência incontornável, que a facilitação e a vulgarização não desfazem. Ao contrário, só fazem complicar e dificultar ainda mais a incontornável tarefa de enfrentar a argumentação cerrada e, não raras vezes, problemática que o autor procurou, no entanto, preparar com cuidado e rigor.

No que diz respeito aos temas sobre os quais o presente artigo se debruça, é facilmente constatável, que, ao longo da volumosa obra em questão, um dos empenhos mais marcantes de Lukács foi o de demonstrar que a inserção social do indivíduo não é algo artificial, como se individualidade e sociabilidade fossem esferas estranhas e oclusas uma em relação à outra, mas ele sublinha e procura demonstrar ad nauseam se tratar de um vínculo constitutivo ineliminável de ambas as dimensões, independentemente do fato - em si relevante e que marca o caráter específico do 
estranhamento - de permanecerem ao longo da história (com raras exceções) no interior de uma relação contraditória. ${ }^{7}$

Nesse passo, é necessário recordar que, sempre de acordo com Lukács, a personalidade de cada indivíduo é resultado de escolhas que ele realiza ao longo da vida. Se tais escolhas são realizadas a partir de um "campo de possíveis", isso não modifica no essencial a questão aqui ventilada, pois, "[...] o curso da vida de qualquer ser humano consiste numa cadeia de decisões, que não é uma sequência simples de decisões heterogêneas, mas sempre se refere espontaneamente ao sujeito da decisão" (LUKÁCS, 2010, p. 91). Ao chamar atenção para o caráter autoconstitutivo da individualidade, ou seja, a dimensão ativa do sujeito diante das pressões e limites de seu "campo de possíveis" postos na vida social, tem-se aqui mais um elemento para compreendermos a preocupação de Lukács em sua obra derradeira. Em outras palavras, qual é a "margem de manobra" do indivíduo diante do desenvolvimento das forças produtivas, que se dão no nível do gênero, mas, sobretudo, sua, repito, "margem de manobra" diante da reificação que se manifesta na vida cotidiana? A resposta a essa questão ficará para outra oportunidade...

O que importa ressaltar nesse passo é que Lukács não deixa margem para dúvidas: "O processo de constituição da individualidade é longo e complicado na exata medida em que é fundado sobre os pôres teleológicos da atividade, em qualquer nível que ela se desenvolva" (VAISMAN, 2009, p. 454). Reconhece e determina que a emergência da individualidade é fruto de:

\footnotetext{
Um longo desenvolvimento das relações sociais, que inicialmente é lentíssimo, para fazer emergir como real e, sobretudo, como universal o problema da individualidade [...] Esse processo, que se desenvolve no plano subjetivo e objetivo, na constante interação entre subjetividade e objetividade, é aquilo que faz nascer as bases ontológicas por meio das quais a singularidade originária do ser humano em vários aspectos ainda simplesmente natural, pode assumir pouco a pouco o caráter da individualidade (que é social, que é possível somente na sociabilidade) (LUKÁCS, 2010, p. 78 modif.).
}

Temos na citação acima importante caracterização não só a respeito do caráter histórico do surgimento e transformação da individualidade, mas também de seus laços constitutivos com a atividade concreta dos próprios indivíduos. Trata-se, é bom frisar, de um processo constitutivo tanto da dimensão subjetiva quanto da objetiva

\footnotetext{
${ }^{7}$ Evidentemente, não se trata aqui de avaliar em que medida Lukács seguiu ou não as concepções de Marx, mas nesse caso específico, não há como deixar de reconhecer as semelhanças entre ambas as formulações.
} 
que ocorre simultaneamente, o que implica reconhecer a construção da individualidade a partir das respostas singulares práticas que se verificam em decorrência das múltiplas demandas que o mundo social coloca para os agentes singulares.

\title{
A determinação social do pensamento e a filosofia
}

Embora se constitua em tarefa essencial, creio que ainda não é este o lugar para expor de modo adequado o longo e sinuoso itinerário intelectual de György Lukács. Tal empreitada só faria sentido se resultasse de esforço de vários pesquisadores, orientados por cuidado, rigor e profundidade, voltado à decifração das etapas de sua vida e à complexidade de suas obras. ${ }^{8}$

O que se pretende nesse artigo, evidentemente, é muito mais modesto, muito embora aspire estabelecer, em traços gerais, o modo como Lukács articulou a noção de determinação social do pensamento. Porém, não é fácil, em poucas linhas, identificar e expor de modo convincente um tema desse teor junto à obra tão intricada e diversa do autor. ${ }^{9}$ Contudo, há indicações que permitem supor que, ao menos desde História e Consciência de Classe, houve da parte do autor:

\begin{abstract}
Um esforço intelectual marcante no sentido de pôr em evidência um campo de reflexão teórica, até então relegado a segundo plano. De fato, [...] se revestiu de importância decisiva, na medida que representou a tentativa independentemente de seus embaraços e malogros - de reconhecer e ressaltar a natureza e as complexas funções da esfera ideológica (VAISMAN, 1996, p. 57).
\end{abstract}

Todavia, nesse momento específico de seu itinerário, tal esforço acabou por se converter numa espécie de autonomização e hipertrofia da esfera subjetiva em detrimento das condições objetivas de sua efetivação, como o próprio Lukács reconhece no afamado Prefácio de 1967 à referida obra.

A despeito do prestígio auferido por livros como Alma e as formas e Teoria do romance, que foram simplesmente deixados para trás, a partir dos anos 1930, já adepto das formulações de Marx, Lukács se dedica febrilmente ao campo da análise das obras de arte, em especial da literatura, "onde a alma do filósofo húngaro encontrou, mais do que qualquer outra parte, os horizontes infinitos de que carecia

\footnotetext{
${ }^{8}$ Ronaldo V. Fortes e eu perseguimos um intento dessa natureza na apresentação ao livro Prolegômenos para uma ontologia do ser social, de autoria de G. Lukács, publicado pela Boitempo editorial em 2010. Contudo, passados onze anos desde aquela publicação, creio que determinadas formulações ali contidas necessitam ser revistas, a partir do avanço das pesquisas que temos realizado.

9 Também por essa razão não iremos contemplar as várias polêmicas que foram criadas em torno da sua trajetória intelectual como, por exemplo, aquela que afirma a superioridade do Lukács pré-marxista frente à sua suposta involução na fase posterior.
} 
para se expandir e frutificar" (VAISMAN; PATRIOTA, 2008, p. 8). Contudo, os cerca de 30 anos que separam o início do percurso do autor e suas obras de plena maturidade como a Estética e Para uma ontologia do ser social, incluídos aí seus Prolegômenos, além de serem marcados por escritos que contribuíam decisivamente para um cenário carente de formulações analíticas sobre a arte inspiradas em Marx, permitem constatar a existência de um projeto de cariz eminentemente filosófico, em que estão presentes de modo indelével o tema que aqui nos preocupa. Exemplos monumentais desse empreendimento, além, é óbvio, de seus trabalhos de análise literária, são os livros $O$ jovem Hegel (cujo término da redação se deu em 1938, mas a publicação apenas dez anos depois) e $A$ destruição da razão (1954), (sem esquecer de Goethe e seu tempo, publicado em 1938), obras que colocaram em xeque, de modo original e competente, teses dominantes no panorama filosófico da época, diga-se de passagem, tanto aquelas esposadas pelos representantes do marxismo oficial quanto de acadêmicos e especialistas renomados que se debruçaram sobre os autores tratados.

Além de trazer à tona características e dimensões do pensamento do jovem Hegel, por exemplo, até então inexploradas, ou seja, os vínculos entre a economia política clássica, notadamente Adam Smith, e a dialética hegeliana, Lukács afirma 0 ponto de partida da investigação, cujos resultados são expostos no livro em questão: "Hegel é precursor da dialética materialista de Marx" (LUKÁCS, 2018, p. 20). Independentemente da correção ou falsidade do ponto de partida que deu ensejo ao caminho analítico percorrido por Lukács, o que importa destacar, em primeiro lugar, é o empenho do autor em desfazer a versão fascistizante na tentativa em "fazer de Hegel um irracionalista conveniente aos fascistas" (LUKÁCS, 2018, p. 54) e, em segundo lugar, a diretiva que orienta a investigação realizada pelo filósofo húngaro, qual seja identificar "o componente histórico-social" e não meramente biográfico com vistas a fornecer a explicação possível "para o desdobramento do método dialético no interior dela [filosofia clássica alemã] até chegar à versão hegeliana da dialética" (LUKÁCS, 2018, pp. 54-55), sobretudo a Revolução Francesa.

Com esse propósito em mente - do mesmo modo que mais tarde irá proceder quando da redação de $A$ destruição da razão - Lukács dedicou várias porções do livro à exposição do desenvolvimento histórico-social da Alemanha, bem como as possíveis repercussões de acontecimentos que marcaram o continente europeu, nas quais afirma o que se segue: 
Hegel não só detém, na Alemanha, a compreensão mais elevada e justa da essência da Revolução Francesa e do período napoleônico, como é, ao mesmo tempo, o único pensador alemão que analisou seriamente os problemas da Revolução Industrial na Inglaterra; ele foi o único a estabelecer uma conexão entre os problemas da economia inglesa clássica e os problemas da filosofia, ou seja, os problemas da dialética (LUKÁCS, 2018, p. 61).

As conclusões a que chega Lukács resultaram de uma extensa e pormenorizada investigação junto aos escritos de Hegel datados de 1793 a 1807 em que, ao lado da identificação de clivagens cruciais de seu itinerário juvenil, é revelado não apenas seu significado no interior da filosofia clássica alemã, como também o modo com que se articula aos eventos socioeconômicos e políticos da sociabilidade capitalista de então. Contundente em suas conclusões, Lukács evidencia nessa volumosa obra a intricada e complexa rede de relações entre a filosofia de um grande autor e as agruras de seu tempo, sem resvalar, sequer por um instante, para relações rasas e mecânicas entre filosofia e sociedade.

O mesmo pode ser dito a respeito do polêmico livro $A$ destruição da razão. Nesse caso específico, o alvo do autor é investigar a trajetória do irracionalismo alemão até o momento em que emergem as vertentes propriamente nazifascistas. Conforme assinalado na sua apresentação:

O livro apresenta em vários momentos da exposição considerações acuradas sobre a constituição do fenômeno do imperialismo em geral, de um lado, e como o fenômeno se constituiu de modo particular em território alemão, de outro. A averiguação das condições econômicas, sociais e políticas de tal contexto histórico tornou-se assim crucial para a devida análise das visões de mundo que se instalaram no seio das posições teóricas pesquisadas. Como é evidente, não se trata de postulações mecânicas acerca das relações entre modos de pensar e o chão social de onde emergem, mas acima de tudo do reconhecimento de sua vinculação inextrincável, sem o que é inconcebível a própria vida humana enquanto tal (VAISMAN; Fortes, 2020, p. XII).

À primeira vista, a partir de uma posição professoral pretensamente neutra, como aquelas descritas na primeira parte do presente artigo, questionamentos no campo filosófico com relação às possibilidades e limites do conhecer são concebidos como entraves ahistóricos insuperáveis, derivados da natureza inevitavelmente manipulatória da ciência, identificada que é - tout court - com a pecha de positivismo e estigmatizada por conta de seus métodos quantitativos. Posicionamentos esses que atribuem ainda tais limites ao caráter derrelito do homem, simplesmente lançado no mundo, em que a intuição passa a ser valorizada em detrimento da razão etc., parecem não ter qualquer tipo de influência sobre a vida cotidiana, sobre os embates travados e os dilemas que vicejam na vida social. Seriam puras manifestações de individualidades supostamente superiores dedicadas a cultivar o jardim de sua própria 
interioridade.

No entanto, avaliações acerca da fratura intrínseca entre filosofia e sociedade parecem carecer de amparo na realidade e se mostram puramente ilusórias. Basta observamos o que se passa em nosso entorno e sair, pelo menos por um instante, do "casulo filosófico" para perceber que formulações destituidoras do humano estão aí a todo vapor a engrossar posicionamentos altamente regressivos, disseminados em todos os espaços da cotidianidade e da vida social em seu conjunto, tanto no Brasil como no mundo afora.

As descobertas de Lukács acerca da trajetória do irracionalismo alemão evidenciaram como uma corrente de formulações diversas no campo filosófico - digase de passagem não possuíam vínculos diretos com a ideologia propriamente nazifascista - contribuíram para a formulação de um caudal que nutriu - direta ou indiretamente - o florescimento do nazifascismo.

Contudo, de acordo com o próprio Lukács, ao avaliar a cena filosófica do pósguerra, a influência daquelas formulações filosóficas, analisadas por ele no referido livro, não se limitou aos eventos que precederam à eclosão da Segunda Guerra Mundial, ao contrário, simultaneamente ao reconhecimento que apesar do:

Irracionalismo puro e simples não desempenha[r] hoje um papel dirigente como o dos tempos da organização da segunda conflagração mundial, [...] ainda constitui uma atmosfera, por assim dizer, ideológica da nova propaganda de guerra; ao menos não desempenha nela um papel desimportante. A advertência aqui proposta para se aprender com o passado não perdeu de modo algum sua atualidade só porque as condições atuais se modificaram sob muitos aspectos. Tanto menos porquanto uma série de elementos que foram decisivos no irracionalismo "clássico" no tempo de Hitler ainda cumpre um papel em nada reduzido, às vezes até acentuado, na propaganda da 'guerra fria' (agnosticismo, relativismo, nihilismo, tendência para a criação de mitos, acriticidade, credulidade, fé em milagres, preconceitos de raça, ódio racial etc., etc.)" (LUKÁCS, 2020, p. 83).

Se o próprio Lukács reconhece que a presença das posturas irracionalistas embora diferentes de sua forma "clássica" (ou seja, alemã) - continuou a vicejar nos tempos da "guerra fria", que dizer dos tempos atuais, em que tais tendências ampliadas e diversificadas, com um sem-número de adeptos, granjeiam prestígio ilimitado tanto na esfera acadêmica quanto na vida artística e cultural, arrastando consigo movimentos e figuras de proa que se colocam inclusive no campo da malfadada esquerda? ${ }^{10}$

\footnotetext{
${ }^{10}$ Diante do descalabro que tem assolado o país, é de fato curioso e desconcertante testemunhar os
} 
A essa altura dos acontecimentos, com toda a experiência histórica acumulada ao longo de décadas, em que formulações como aquelas criticamente analisadas por Lukács passaram a desfrutar de modo cada vez mais intenso e ampliado a hegemonia ideológica, penetrando com sucesso nos vários níveis em que se dá atividade intelectual, e repercutindo, de modo cada vez mais intenso, nas formas de pensar e sentir do cotidiano, não é mais possível negar que:

Todo pensamento possui uma gênese social e, assim, cumpre igualmente uma função social específica. Este é o sentido da determinação lukácsiana segundo a qual 'não há filosofia inocente'. Todo pensamento cumpre, nessa medida, uma missão social, aspecto que destaca seu enraizamento nas tendências - contraditórias - postas pela realidade social de dado momento histórico. O irracionalismo no campo da filosofia não é, desse modo, apenas uma tendência filosófica nascida da disputatio interna do pensamento ocidental. No caso específico do pensamento alemão, ele reflete tendências sociais oriundas particularmente do processo de transição alemão para o capitalismo. Lukács resgata o caráter conservador desse trânsito para a forma da sociabilidade capitalista [...] (VAISMAN; FORTES, 2020, p. XIII).

Sendo assim:

Tal como Lukács demonstra à exaustão, as concepções por ele analisadas sobretudo aquelas de Nietzsche e Heidegger - inibem o pensamento e desmobilizam a ação, tanto no nível singular quanto no plano mais geral da vida humana. Por isso mesmo e graças a um complexo conjunto de condicionantes sociais e econômicas, visões de mundo matrizadas por vertentes irracionalistas se encontram amplamente difundidas no interior da própria vida cotidiana, sem que tal presença seja percebida e conscientizada como tal. Todo um conjunto de concepções cuja origem se encontra na esfera filosófica passa assim a orientar as ações dos indivíduos (VAISMAN; FORTES, 2020, p. XVII).

A partir da pesquisa exaustiva e rigorosa junto aos textos de vários expoentes da filosofia alemã dos séculos XIX e XX, Lukács reuniu as condições necessárias para afirmar, em especial, a presença de traços marcantes da filosofia nietzschiana no seio da vida cotidiana, nos seguintes termos:

As massas foram fortemente envenenadas por tais ideologias sem que jamais tenham colocado os olhos sobre a fonte direta do envenenamento. A barbarização nietzschiana dos instintos, sua filosofia da vida, seu "pessimismo heroico" etc. são produtos necessários do período imperialista, e o aceleramento desse processo provocado por Nietzsche pôde surtir efeito

comentários críticos de personagens com grande influência, inclusive nos meios midiáticos, esbravejando contra as posturas negacionistas do atual presidente da república, quando até ontem se empenhavam na condenação da ciência e da técnica, concebidas como causadoras das desgraças humanas. São de fato comuns, principalmente no meio universitário, a disseminação de modismos teóricos que vão desde a execração - por princípio - da ciência e da técnica até aqueles que denunciam o controle dos corpos pelo Estado, valendo-se da noção de biopolítica, que, se examinados de modo isento, corroboraram as posturas execráveis do negacionismo. (É bom lembrar que o movimento antivacina, a homeopatia, a astrologia e outras vertentes do mesmo talhe lograram a adesão de segmento expressivo de personalidades que se colocam à esquerda do espectro político, o que demonstra a capilaridade das posições aqui denunciadas). 
em milhares e milhares de pessoas que sequer conheciam o seu nome (LUKÁCS, 2020, p. 77).

Depois dessa avaliação decisiva e contundente acerca do modo como as formulações filosóficas - quaisquer que sejam - chegam a influenciar posturas e reações práticas na órbita do cotidiano, é possível perceber as razões que levaram Lukács a dedicar parte de sua obra postumamente publicada ao problema da ideologia. Foram vários anos de dedicação e pesquisa junto a tendências e autores diversos, tanto no campo da filosofia quanto da arte, notadamente a literatura, que propiciaram ao autor tematizar sob uma perspectiva ontológica as formações ideológicas, contrariando, portanto, as interpretações correntes amparadas sobretudo no critério gnosiológico. Como é sabido, tais abordagens acabaram por consagrar a identidade entre ideologia e falsidade, o que é questionado vivamente por Lukács.

Não por acaso também que, ao tratar do tema, determina a filosofia, ao lado da arte, como forma pura de ideologia. Como será possível constatar nas linhas que se seguem, o autor fornece um conjunto de elementos com o objetivo de esclarecer 0 modo como a filosofia exerce sua influência em termos ideológicos.

Talvez seja o caso lembrar aqui mais uma vez a imagem já referida que Lukács recorre no prefácio da Estética de 1963 para ilustrar o evolver histórico humano no curso da história, em que diferentes modos de atividade de desenvolvem e se autonomizam progressivamente para constituir esferas específicas, regidos por leis próprias, mas que a partir de múltiplas mediações têm origem e voltam a essa esfera de origem constantemente para se fundar e, ao mesmo tempo, influenciar esse âmbito da vida. Esses domínios da atividade, diz Lukács, encontram na vida cotidiana sua fonte e seu ponto de chegada:

O comportamento cotidiano do homem é ao mesmo tempo começo e fim de
toda atividade humana. Se representarmos a cotidianidade como um grande
rio, pode-se dizer que dele se desprendem [...] a ciência e a arte, [que] se
diferenciam, se constituem de acordo com suas finalidades específicas,
alcançam sua forma pura nessa especificidade [...] para, portanto, em
consequência de seus efeitos, de sua influência na vida dos homens,
desembocar de novo na vida cotidiana (LUKÁCS, 1965, pp.11-12).

Ressalte-se, no entanto, que tal influência depende, para seu pleno exercício, que demandas surgidas na vida cotidiana sejam, de algum modo, reconhecidas e atendidas a partir das respostas dadas pelas formações ideais. Consciente do caráter dessa interrelação, na parte introdutória de Para uma ontologia do ser social, Lukács identifica o lócus preciso de onde brotam as necessidades a atender pelas formações ideais. Ele diz: 
A práxis postula por si só, necessariamente, uma imagem do mundo com a qual possa harmonizar-se e a partir da qual a totalidade das atividades vitais produz um contexto pleno de sentido. É claro que a ciência e a filosofia a ela vinculada são chamadas em primeiro lugar a oferecer uma resposta adequada [...] como partes da inteira realidade social (LUKÁCS, 2012, p. 31).

É evidente, que ao reconhecer o papel que a filosofia cumpre, enquanto forma de ideologia pura, Lukács rejeita o modo como convencionalmente esse tipo de saber é concebido. De acordo com ele, a filosofia;

Nunca constitui um fim em si mesmo, nunca é uma síntese meramente
enciclopédica ou pedagógica de resultados acreditados, mas uma
sistematização, como meio de possibilitar a compreensão mais adequada
possível desse 'de-onde' e 'para-onde' do gênero humano" (LUKÁCS, 2013,
p. 540).

E acrescenta:

Não existe filósofo que realmente mereça essa designação, não só no sentido estritamente acadêmico, cujo pensamento não esteja direcionado para interferir decisivamente nos conflitos decisivos de seu tempo, elaborar princípios de seu enfrentamento e resolução e, por essa via, imprimir a esse enfrentamento um rumo mais decidido" (LUKÁCS, 2013, p. 541).

Consequentemente, o papel das formas ideológicas puras - no caso aqui a filosofia - por sua própria natureza e escopo é o de não intervir diretamente, pois não possuem os próprios meios para tal, no ambiente socioeconômico conflituado. Diferentemente da política e do direito, o âmbito de influência da filosofia está diretamente relacionado com questões humanas universais e expressam um "determinado nível evolutivo da relação individualidade/generidade - os dois polos fundamentais do ser social -, ao mesmo tempo em que desempenham importante função subjetiva no processo de socialização enquanto tal" (VAISMAN, 2010, p. 56).

Conclui-se assim que, de acordo com a caracterização lukácsiana, "a filosofia é uma área do conhecimento interessado, interessada pelo destino do homem, pela sua essência, voltada às questões que dizem respeito ao gênero humano, e jamais se esgotando num simples conjunto de conhecimentos voltados exclusivamente para si mesmos" (VAISMAN, 2010, p. 56).

Em suma, segundo a reflexão lukácsiana, a filosofia se revela como forma específica de ideologia na sua peculiaridade de forma pura. Pura na medida em que, de um lado, as questões sobre as quais se expressa ultrapassam a imediaticidade cotidiana (âmbito do direito) e também a globalidade social conflituada, que é o território da política; e, de outro, se caracteriza por não dispor de meios próprios, ao contrário dos aparatos políticos, para colocar em prática as suas generalizações. 
De tal modo e a seu modo, a filosofia age como ideologia. Mas, aqui também, como em outros casos, não se pode nem se deve pensar em efeitos simplesmente automáticos e mecânicos, de acordo com o pensamento de Lukács, várias vezes ressaltado. O aspecto crucial desse tipo de tematização, ao contrário do que é propalado nos ambientes acadêmicos, a influência ideológica da filosofia se faz presente na própria vida cotidiana, na medida em que as formulações filosóficas acabam inevitavelmente desaguando nessa esfera da vida, ainda que seu fazer pressuponha um certo tipo de distanciamento. Lukács exemplifica na mesma linha de avaliação contida e já referida no livro $A$ destruição da razão: "não é preciso ter lido Marx para reagir em termos de classe aos acontecimentos do dia; não é preciso vivenciar artisticamente Dom Quixote ou Hamlet para ser influenciado por eles" (LUKÁCS, 2013, p. 561). Essas influências exercidas pelas formas ideológicas puras podem ser regressivas ou progressivas. Neste sentido, Lukács acrescenta de forma incisiva: "Isso [a influência ideológica] é assim tanto no bem quanto no mal - o que no campo ideológico, nem pode ser diferente; tampouco foi necessário estudar Nietzsche ou Chamberlain para tomar decisões fascistas" (LUKÁCS, 2013, p. 561).

Com vistas a encaminhar a parte conclusiva do presente artigo, vale a pena sintetizar agora alguns pontos para o devido entendimento do problema sobre as relações entre filosofia e sociabilidade. Segundo Lukács, em primeiro lugar, a filosofia "une, portanto, sinteticamente os dois polos, mundo e homem, na imagem da generidade concreta" (LUKÁCS, 2013, p. 543). A filosofia, forma pura de ideologia, realiza esta tarefa na medida em que seu "objeto central é o gênero humano, isto é, uma imagem ontológica do universo - e, dentro desta, da sociedade a partir do aspecto de como ela realmente foi, veio a ser e é para que se produzisse como necessário e possível cada um dos tipos atuais de generidade" (LUKÁCS, 2013, p. 543). Ou seja:

A filosofia perfaz o exame e especificação da generidade, estando implicado, pois, a própria socialização da sociedade, o que compreende intelecções e posse de mundo. É sobre o que se pronuncia a filosofia, como prévia-ideação dos embates do homem em seu 'de-onde para-onde', enquanto generalidade humana no mundo. (VAISMAN, 2010, p. 57)

À primeira vista, uma leitura superficial e descuidada do texto lukácsiano poderia inferir que se trata de uma proposta desvirtuadora da natureza intrínseca da atividade filosófica, na medida em que, supostamente, introduz um elemento estranho, desfigurador ou espúrio no interior dessa esfera, como indicado no início das nossas 
considerações sobre o tema, nas páginas iniciais desse artigo. Nada mais equivocado, sobretudo se considerarmos que o valor das grandes obras filosóficas reside justamente no fato de refletir acerca dos grandes dramas humanos prementes em cada momento do tempo. Depreciação ocorre quando se restringe e se limita o seu valor ao se desconhecer o papel que suas formulações desempenham para a vida humana em sociedade, para o bem ou para o mal. Para o mal, como parece ser o caso que nos interessa nesse momento do século XXI, com suas tendências regressivas persistentes, cujas origens radicam, em grande medida, nas filosofias examinadas por Lukács. Ou seja, queiramos ou não, gostemos ou não, o que se passa no universo filosófico aparentemente tão evanescente e distante - deságua na vida cotidiana, pois dela partiu, trazendo consigo suas dores e as possíveis direções a seguir, para frente ou para trás.

Consequentemente, a determinação ontológica da filosofia como forma de ideologia pura não a reduz, nem a desqualifica. Ao contrário, desvela sua eficácia própria, ao dar por conhecida sua gênese e sua finalidade, indissoluvelmente ligadas à humanidade urdida pela sociabilidade, as quais, a seu modo, mas de fato, ajuda a construir.

Por último, nunca é demais sublinhar, as conclusões a que o filósofo húngaro chegou a esse respeito foram fruto de uma vida inteira dedicada ao estudo e ao embate crítico de obras literárias e filosóficas, além de ter mantido - certo ou errado, aqui não importa - intensa polêmica com as correntes político-ideológicas (tanto à direita quanto à esquerda) que dominaram o século $X X$, e cujos adeptos e seguidores contumazes continuam a dominar o cenário, em nada encorajador. Certamente tais atributos do autor aqui referido não podem ser desconhecidos ou subestimados, independentemente dos erros, acertos, sucessos e fracassos que pontuaram sua vida.

\section{Referências bibliográficas}

ADORNO, T. W. Dialética Negativa. Trad. de Marco Antônio Casanova. Rio de Janeiro: Zahar, 2009.

CHASIN. J. Marx. estatuto ontológico e resolução metodológica. São Paulo: Boitempo, 2009.

HOLZ, H. H., Kofler, L.; Abendroth, W. Conversando com Lukács. Trad. Giseh Viana Konder Rio de Janeiro: Paz e Terra, 1969.

LEFORT, C. "Esboço de uma gênese da ideologia nas sociedades modernas". Trad. Luiz Roberto Salinas Fortes e Marilena Chauí. In: LEFORT, C. As formas da História, São Paulo: Brasiliense, 1979. 
LUKÁCS, G. Estética (La peculiaridad de lo estético). Trad. Manuel Sacristán v. I. Barcelona: Editorial Grijalbo, 1965.

LUKÁCS, G. Para uma ontologia do ser social. Trad. Carlos Nelson Coutinho, Mario Duayer e Nélio Schneider. v. I. São Paulo: Boitempo, 2012.

LUKÁCS, G. Para uma ontologia do ser social. Trad. Nélio Schneider. v. II. São Paulo: Boitempo, 2013.

LUKÁCS, G. Prolegômenos para uma ontologia do ser social. Trad. Lya Luft e Rodnei Nascimento. São Paulo: Boitempo, 2010.

MARX, K. Teorias da mais-valia (História crítica do pensamento econômico). Trad. Reginaldo Sant'Anna. v. I. Rio de Janeiro: Civilização Brasileira, 1980.

MARX, K. Teorias da mais-valia (História crítica do pensamento econômico). Trad. Reginaldo Sant'Anna. v. II. Rio de Janeiro: DIFEL, 1983.

MARX, K. Teorias da mais-valia (História crítica do pensamento econômico). Trad. Reginaldo Sant'Anna. v. III. Rio de Janeiro: Civilização Brasileira, 1985.

MARX, K. Engels, F. A ideologia Alemã. Trad. Rubens Enderle, Nélio Schneider, Luciano Martorano. São Paulo: Boitempo, 2007.

VAISMAN, Ester. A determinação marxiana da ideologia. 1996. Tese (Doutorado) apresentada à Faculdade de Educação da Universidade Federal de Minas Gerais, Belo Horizonte, 1996.

VAISMAN, E. "A usina onto-societária do pensamento". Verinotio - Revista On-line de Educação e Ciências Humanas. n. 4, Ano II, abr./2006.

VAISMAN, E. "Dossiê Marx: Itinerário de um grupo de pesquisa". Verinotio - Revista On-line de Educação e Ciências Humanas. n. 4, Ano Il, abr./2006.

VAISMAN, E. "Editorial - 200 anos de Marx Ou: o que foi feito de pensamento de Marx?" Verinotio - revista on-line de filosofia e ciências humanas. v. 24, n. 2 , nov./2018. Disponível em: <http://www.verinotio.org/sistema/index.php/verinotio/article/view/354/338>. Acesso em: 26/05/2021.

VAISMAN, E. "Marx e Lukács e o problema da individualidade: algumas aproximações." Perspectiva, Florianópolis, v. 27, npp. 441-459, jul./dez. 2009.

VAISMAN, E.; Alves, A. J. L. Prefácio a Chasin, J. Marx - Estatuto Ontológico e Resolução Metodológica. São Paulo: Boitempo, 2009.

VAISMAN, E.; FORTES, R. V. Apresentação a LUKÁCS, G. $A$ destruição da razão. São Paulo: Instituto Lukács, 2020.

VAISMAN, E.; PATRIOTA, R. C. Apresentação a TERTULIAN, N. Georg Lukács - Etapas de seu pensamento estético. São Paulo: UNESP, 2003.

VAISMAN, E. A ideologia e sua determinação ontológica. Verinotio - Revista de Educação e Ciências Humanas, n.12, ano VI, 2010.

WITTGENSTEIN, L. Tractatus Logico-Philosophicus. Trad. J. A. Giannotti. São Paulo: Nacional/ EDUSP, 1963.

WITTGENSTEIN, L. Investigações Filosóficas. Trad. José Carlos Bruni Coleção Os Pensadores, v. XLVI, São Paulo: Abril Cultural, 1975. 
Como citar:

VAISMAN, Ester. O que é possível dizer sobre as relações entre filosofia e sociedade em pleno século XXI?. Verinotio, Rio das Ostras, v. 27, n. 1, pp. 277-307, jan./jun 2021. 